University of Nebraska - Lincoln

DigitalCommons@University of Nebraska - Lincoln

Faculty Publications: Department of Entomology

Entomology, Department of

6-1-2004

\title{
Characterization of Oxidative Enzyme Changes in Buffalograsses Challenged by Blissus occiduus
}

\author{
Tiffany Heng-Moss \\ University of Nebraska-Lincoln, thengmoss2@unl.edu \\ Gautam Sarath \\ University of Nebraska-Lincoln, Gautam.sarath@ars.usda.gov \\ Frederick P. Baxendale \\ University of Nebraska-Lincoln, fbaxendale1@unl.edu \\ Dana Novak \\ University of Nebraska-Lincoln \\ Shauna Bose \\ University of Nebraska-Lincoln \\ See next page for additional authors
}

Follow this and additional works at: https://digitalcommons.unl.edu/entomologyfacpub

Part of the Entomology Commons

Heng-Moss, Tiffany; Sarath, Gautam; Baxendale, Frederick P.; Novak, Dana; Bose, Shauna; Ni, Xinhi; and Quisenberry, Sharron, "Characterization of Oxidative Enzyme Changes in Buffalograsses Challenged by Blissus occiduus" (2004). Faculty Publications: Department of Entomology. 118.

https://digitalcommons.unl.edu/entomologyfacpub/118

This Article is brought to you for free and open access by the Entomology, Department of at DigitalCommons@University of Nebraska - Lincoln. It has been accepted for inclusion in Faculty Publications: Department of Entomology by an authorized administrator of DigitalCommons@University of Nebraska - Lincoln. 


\section{Authors}

Tiffany Heng-Moss, Gautam Sarath, Frederick P. Baxendale, Dana Novak, Shauna Bose, Xinhi Ni, and Sharron Quisenberry 


\title{
Characterization of Oxidative Enzyme Changes in Buffalograsses Challenged by Blissus occiduus
}

\author{
TIFFANY HENG-MOSS,${ }^{1}$ GAUTAM SARATH, ${ }^{2}$ FREDERICK BAXENDALE, DANA NOVAK, ${ }^{2}$ \\ SHAUNA BOSE, ${ }^{2}$ XINHI NI, ${ }^{3}$ AND SHARRON QUISENBERRY ${ }^{3}$
}

Department of Entomology, University of Nebraska, Lincoln, NE 68583

\begin{abstract}
J. Econ. Entomol. 97(3): 1086-1095 (2004)
ABSTRACT This research investigated the role of oxidative enzymes in the defense response of buffalograss, Buchloë dactyloides (Nuttall) Engelmann, to Blissus occiduus Barber. Changes in catalase and peroxidase activity were observed in both resistant and susceptible buffalograsses in response to chinch bug feeding. Susceptible plants were shown to have a lower level of catalase activity compared with their respective control plants. By contrast, catalase activities of resistant plants were similar between infested and control buffalograsses throughout the study. Resistant plants had higher levels of peroxidase activity compared with their control plants, whereas peroxidase activities for control and infested susceptible plants remained at similar levels or were slightly lower for infested plants. These findings suggest that chinch bug feeding leads to a loss in catalase activity in susceptible buffalograsses. In contrast, resistant buffalograsses may be able to tolerate chinch bug feeding by increasing their peroxidase activity. Polyphenol oxidase activities were similar between control and infested plants for the buffalograsses evaluated. Among the enzymes examined, no differences in isozyme profiles for peroxidase and polyphenol oxidase were detected between control and infested 378, NE91-118, Cody, and Tatanka plants. Gels stained for catalase identified differences in the isozyme profiles of infested and uninfested 378 plants; however, infested and control NE91-118, Tatanka, and Cody plants has similar isozyme profiles. No differences in protein profiles were observed between chinch buginfested 378, NE91-118, Cody, and Tatanka plants and their respective uninfested controls.
\end{abstract}

KEY WORDS oxidative enzymes, peroxidase, catalase, polyphenol oxidase, plant resistance

IN RECENT YEARS, RESEARCHERS HAVE placed increased emphasis on the development of effective, nonchemical control strategies for managing insect pests affecting agronomic crops and turfgrasses. Plant resistance offers a promising approach for managing insect pests because it is sustainable, economical, and environmentally responsible. When developing insect-resistant crops and turfgrasses, a thorough understanding of the underlying mechanisms of the resistance is critical for formulating optimal strategies for identifying and exploiting new resistant sources. Although considerable progress has been made in identifying germplasm resistant to insect pests, progress toward characterization of the physiological and biochemical mechanisms conferring the resistance remains limited.

Modifications in plant protein profiles and alterations in plant oxidative enzyme levels have been reported to be among a plant's first response to insect herbivory (Green and Ryan 1972; Hildebrand et al. 1986; Felton et al. 1994a,b; Miller et al. 1994; Rafi et al.

\footnotetext{
${ }^{1}$ E-mail: tiffany@unlserve.unl.edu.

${ }^{2}$ Department of Biochemistry, University of Nebraska, Lincoln, NE 68588 .

${ }^{3}$ Department of Entomology, Montana State University, Bozeman, MT 59717.
}

1996; Stout et al. 1999; Chaman et al. 2001; Ni et al. 2001). Miller et al. (1994), Rafi et al. (1996), and Jerez (1998) have reported changes in plant protein profiles in resistant plants after insect feeding. Hildebrand et al. (1986) and Felton et al. (1994a,b) found increased levels of peroxidase activity in response to herbivory by mites, bean leaf beetles, and three-corned alfalfa leafhoppers in resistant soybean. Stout et al. (1999) showed that tomato plants exposed to both pathogens and insects systemically up-regulated peroxidases and polyphenol oxidase. Although different pathogens and insects affected the tomato plants to different extents, all of these stressors resulted in the tomato plants increasing both oxidative enzyme levels. Chaman et al. 2001 showed that barley peroxidases were induced by infestation to aphids. The peroxidases with increased activity in this study were localized in both the cytoplasm and the cell wall. Soluble peroxidases were increased after infestation whether the aphids were introduced to the plant when the plant was $7,10,13$, or $16 \mathrm{~d}$ old. Peroxidases ionically bound to the cell wall were increased in every infested plant, but plants that were $16 \mathrm{~d}$ old when first infested actually showed a decrease in covalently bound cell wall peroxidases. $\mathrm{Ni}$ et al. (2001) evaluated the impact Russian wheat 
aphid, Diuraphis noxia (Mordvilko), feeding has on the oxidative responses of resistant and susceptible cereal leaves. Increased levels of peroxidase activity were observed in wheat leaves from $D$. noxia-resistant plants after aphid feeding, whereas wheat leaves from D. noxia-susceptible plants did not exhibit a similar increase. Conversely, peroxidase activity increased in the $D$. noxia-susceptible barley, but the level of peroxidase activity of the $D$. noxia-resistant oat remained similar with control leaves. $D$. noxia feeding did not elicit any changes in catalase and polyphenol oxidase activities compared with control plants. $\mathrm{Ni}$ et al. (2001) concluded that the different enzymatic responses in wheat, barley, and oat to feeding by the Russian wheat aphid suggest that these cereals have different mechanisms of aphid resistance. These findings suggest that the synthesis or increased expression of specific plant proteins may serve to enhance the plant's resistance to insects. Once identified, these changes may also be useful as markers for pest resistance.

This research investigated the role of oxidative enzymes and other proteins in the defense response of buffalograss, Buchloë dactyloides (Nuttall) Engelmann, to the chinch bug, Blissus occiduus Barber (Baxendale et al. 1999). The objectives were two-fold: first, to compare protein content and enzyme activities (i.e., peroxidase, catalase, and polyphenol oxidase) of chinch bug-resistant and -susceptible buffalograsses; and second, to analyze extracted proteins by native and denaturing gel electrophoresis to obtain information about protein profiles of resistant and susceptible buffalograsses.

\section{Materials and Methods}

Buffalograsses. Four buffalograsses, three resistant cultivars/selections (NE91-118, Cody, and Tatanka) and the susceptible cultivar 378 (Heng-Moss et al. 2002) were selected for protein analyses. Plugs of each buffalograss cultivar/ selection, $10.6 \mathrm{~cm}$ in diameter by $6 \mathrm{~cm}$ in depth, were extracted from buffalograss evaluation plots at the John Seaton Anderson Turfgrass and Ornamental Research Facility (JSA Facility), University of Nebraska Agricultural Research and Development Center, near Mead, NE. Plugs were trimmed to the soil surface and individual buffalograss plants were planted in "SC-10 Super Cell" Single Cell Cone-tainers $(3.8 \mathrm{~cm}$ in diameter by $21 \mathrm{~cm}$ in depth) (Stuewe \& Sons, Inc., Corvallis, OR) containing a potting mixture of sand-soil-peat-perlite in a 0.66 : 0.33:1:1 ratio, and placed under 400-W high-intensity discharge lamps with a photoperiod of 16:8 (L:D) $h$ for 4 wk before starting the study. Cone-tainers were placed in 7 by 14 Cone-tainer trays. Plants were fertilized biweekly with a soluble 20.0:4.4:16.6 (20:10:20) fertilizer.

Chinch Bugs. Chinch bugs were collected from an infested 378 buffalograss evaluation plot at the JSA Facility. The chinch bugs were held in the laboratory for $24 \mathrm{~h}$ before beginning the study. At the start of the study, plants were paired according to similar heights and turf quality. Eight fifth instars were introduced on one plant of each buffalograss pair, whereas the other served as the uninfested control. Tubular, Plexiglas cages $(4 \mathrm{~cm}$ in diameter by $30 \mathrm{~cm}$ in height) served to confine chinch bugs on the plant.

The experimental design was a completely randomized design with three replications. The treatment design was a 4 by 2 by 5 factorial (four buffalograss cultivars/selection, two levels of chinch bug infestation [zero and eight], and five sample dates). The study was conducted in a greenhouse that was maintained at $28 \pm 2{ }^{\circ} \mathrm{C}$.

Sample Collection. Buffalograss samples consisting of the crown, leaf blades, and lower leaf sheaths (20 mg) were collected for protein analyses at 3, 6, 9, 12 , and $15 \mathrm{~d}$ after chinch bug introduction. Before collecting the plant material for protein analyses, chinch bugs were removed from the infested plants and chinch bug damage ratings were performed using a $1-5$ scale, where 1 is $10 \%$ or less damage, 2 is 11 to $30 \%$ damage, 3 is 31 to $50 \%$ damage, 4 is 51 to $70 \%$ damage, and 5 is $71 \%$ or more damage and plant close to death (Heng-Moss et al. 2002). Plant material was frozen in liquid nitrogen and stored at $-80^{\circ} \mathrm{C}$.

Preparation of Buffalograss Samples. Samples were removed from a $-80^{\circ} \mathrm{C}$ freezer, thawed, and prepared for protein analyses by using the following protocol modified from Hildebrand et al. (1986). Soluble proteins were extracted by grinding plant tissues in a chilled mortar with $1.5 \mathrm{ml}$ of $20 \mathrm{mM}$ HEPES buffer (pH 7.2) containing a protease inhibitor cocktail $[0.3 \mathrm{~g} / 1 \mathrm{~g}$ of tissue, contains 4-(2-aminoethyl) benzenesulfonyl fluoride, bestatin, pepstatinA, E-64, leupeptin, and 1,10-phenanthroline, Sigma, St. Louis, MO) and $1 \%$ polyvinylpyrrolidone. The homogenate was centrifuged at $10,000 \times g$ for $10 \mathrm{~min}$ at $4^{\circ} \mathrm{C}$. The supernatant was collected and stored $(<3 \mathrm{~h})$ at $4^{\circ} \mathrm{C}$ until protein analyses.

Protein and Enzyme Assays. The effect of chinch bug feeding on plant protein content and enzyme (peroxidase, polyphenol oxidase, and catalase) activities were examined using a spectrophotometer. Total protein content was measured using a commercially available bicinchoninic acid (BCA) protein assay (Pierce Chemical, Rockford, IL) with bovine serum albumin as a standard (Bradford 1976).

Peroxidase activity was measured by monitoring the increase in absorbance at $470 \mathrm{~nm}$ for 2 min by using a protocol modified by Hildebrand et al. (1986) and Hori et al. (1997). The enzymatic reaction was started by adding $10 \mu \mathrm{l}$ of $30 \%$ hydrogen peroxide to a cuvet containing $300 \mu \mathrm{l}$ of $18 \mathrm{mM}$ guaiacol, $100 \mu \mathrm{l}$ of $200 \mathrm{mM}$ HEPES ( $\mathrm{pH} 7.0$ ), $585 \mu \mathrm{l}$ of distilled water, and $5 \mu \mathrm{l}$ of buffalograss extract. The specific activity of peroxidase was determined using the molar absorptivity of guaiacol at $470 \mathrm{~nm}\left(26.6 \times 10^{3} \mathrm{M}^{-1} \mathrm{~cm}^{-1}\right)$.

Catalase activity was determined according to Hildebrand et al. (1986). The reaction was initiated by adding $25 \mu \mathrm{l}$ of buffalograss extract to a cuvet containing $100 \mu \mathrm{l}$ of $200 \mathrm{mM}$ HEPES (pH 8.0), $775 \mu \mathrm{l}$ of distilled water, and $100 \mu \mathrm{l}$ of $75 \mathrm{mM}$ hydrogen peroxide, and the reaction monitored at $240 \mathrm{~nm}$ for $2 \mathrm{~min}$ 

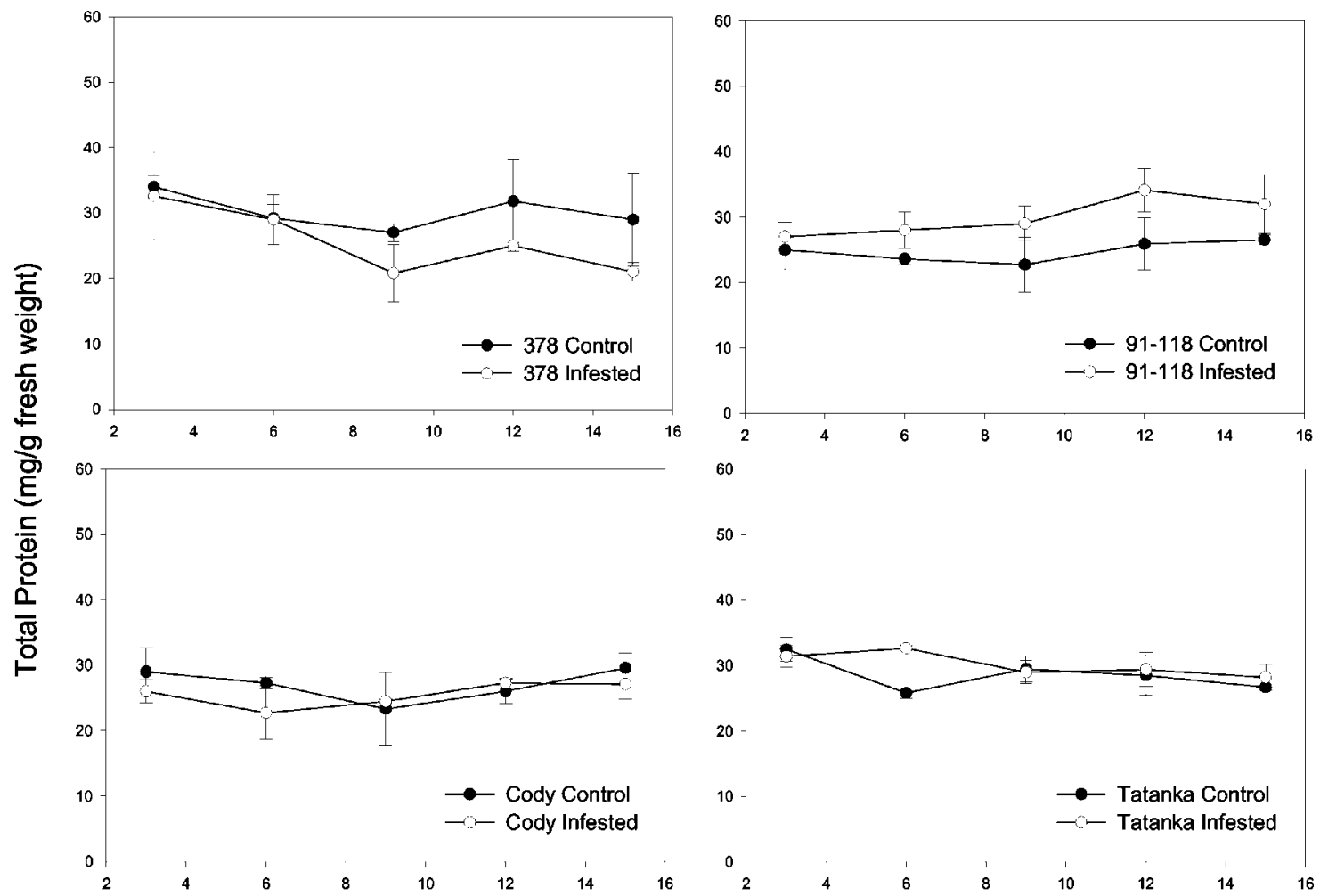

Day

Fig. 1. Total protein content (milligrams per gram of fresh plant weight) of buffalograsses.

after the addition of plant extracts. The specific activity was determined using the molar absorptivity of hydrogen peroxide at $240 \mathrm{~nm}\left(43.6 \mathrm{M}^{-1} \mathrm{~cm}^{-1}\right)$.

Polyphenol oxidase activity was measured following a protocol modified from Hori et al. (1997). Polyphenol oxidase activity was monitored at $470 \mathrm{~nm}$ for 2 min after the start of the reaction. The reaction was initiated by adding $20 \mu \mathrm{l}$ of buffalograss extract to a cuvet containing $500 \mu \mathrm{l}$ of $1.6 \%$ catechol in HEPES buffer, $380 \mu \mathrm{l}$ of distilled water, and $100 \mu \mathrm{l}$ of $200 \mathrm{mM}$ HEPES buffer ( $\mathrm{pH}$ 6.0). Polyphenol oxidase activity was calculated as the change in A470/min mg protein.

Gel Electrophoresis. The plant proteins extracted for the protein and enzyme assays were also analyzed by native and denaturing gel electrophoresis to obtain information about isozyme patterns and total protein profiles.

Native Gel Electrophoresis. Samples were analyzed for isozyme expression by native gel electrophoresis on a Criterion gel apparatus (Bio-Rad, Hercules, CA) by using precast 18 -well $7.5 \%$ polyacrylamide gels (Criterion gel, Bio-Rad). A continuous buffer system of Tris-glycine ( $3 \mathrm{~g}$ of Tris-base, $14.4 \mathrm{~g}$ of glycine, and $1000 \mathrm{ml}$ of distilled water) (pH 8.3) was used. Equal amounts of protein $(35 \mu \mathrm{g})$ as determined by the BCA protein assay (Pierce Chemical) were loaded in each lane. Samples were diluted 1:1 with a gel loading buffer consisting of 62.5 mM Tris- $\mathrm{HCl}$ (pH 6.8), 40\% glycerol, and $0.01 \%$ bromphenol blue before loading. Gels were electrophoresed at $120 \mathrm{~V}$ for $1.5 \mathrm{~h}$ at $4^{\circ} \mathrm{C}$.

Isozyme profiles for peroxidase, catalase, and polyphenol oxidase activity were visualized using histochemical methods. All gels were evaluated for the presence or absence of bands and photographed immediately after incubation and staining. The incubation and staining procedures for the peroxidase, catalase, and polyphenol oxidase were adapted from Vallejos (1983).

Peroxidase. Gels were soaked at room temperature $\left(\approx 25^{\circ} \mathrm{C}\right)$ for $10 \mathrm{~min}$ in $50 \mathrm{mM}$ sodium acetate buffer (pH 5.0). After this initial incubation period, $10 \mathrm{mg}$ of 4-chloronaphthol (dissolved in $0.5 \mathrm{ml}$ of methanol) and $20 \mu \mathrm{l}$ of $30 \%$ hydrogen peroxide were added to the buffer. Zones of peroxidase activity occurred as black bands after $\approx 15 \mathrm{~min}$.

Catalase. Gels were held at room temperature for $5 \mathrm{~min}$ in $50 \mathrm{ml}$ of $0.01 \%$ hydrogen peroxide. Gels were then rinsed with distilled water and placed in a solution of ferric chloride and potassium ferricyanide. The solution was prepared by dissolving $500 \mathrm{mg}$ of ferric chloride and $500 \mathrm{mg}$ potassium ferricyanide in $50 \mathrm{ml}$ of distilled water. Achromatic bands occurred on a dark green background after $\approx 30 \mathrm{~min}$.

Polyphenol Oxidase. Gels were soaked at room temperature for $30 \mathrm{~min}$ in $20 \mathrm{mM}$ HEPES buffer ( $\mathrm{pH} 7.2)$ containing $5 \mathrm{mM}$ DL- $\beta$-(3,4-dihydoxyphenyl) alanine 

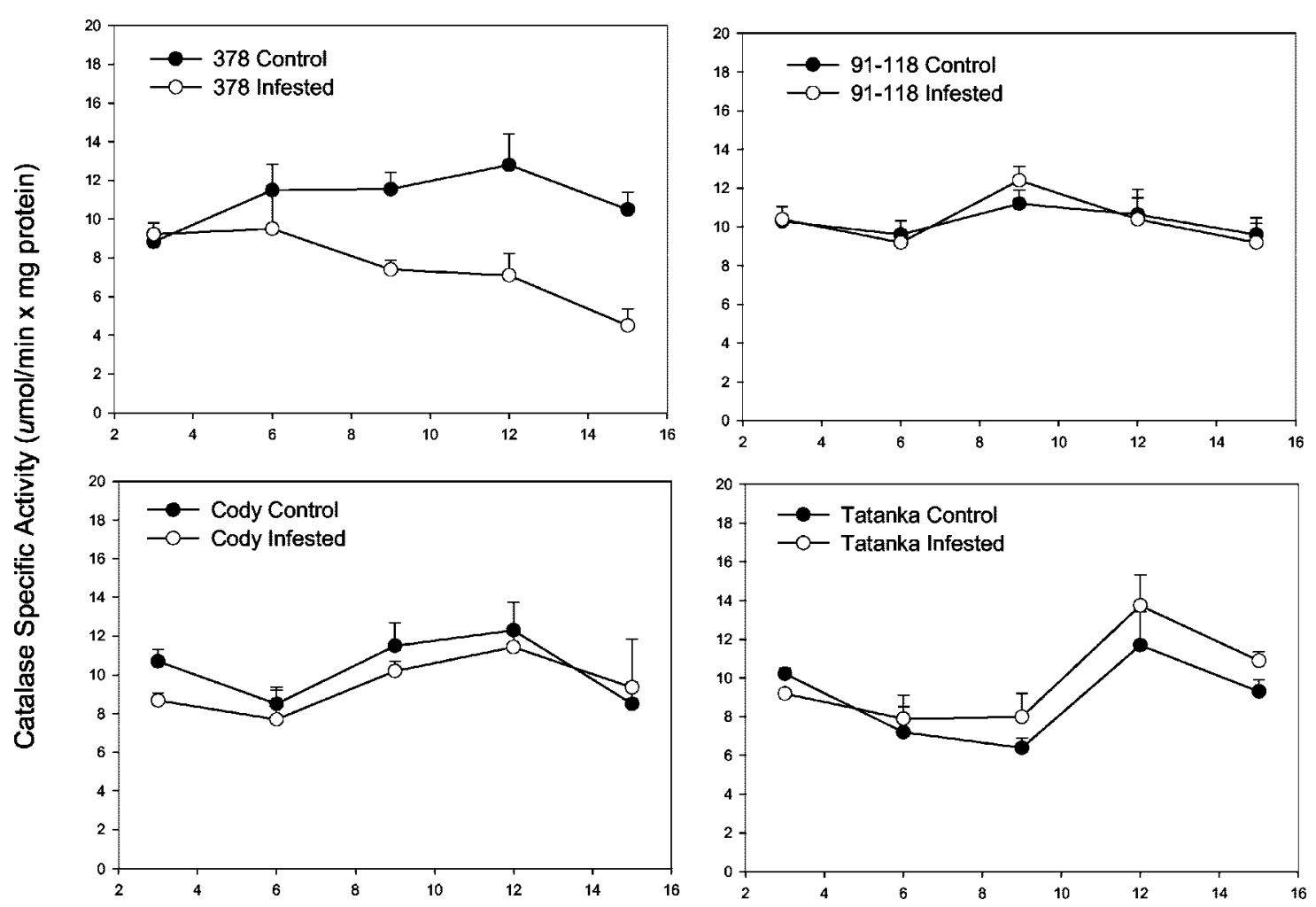

Day

Fig. 2. Catalase specific activity (micromoles per minute $\times$ milligrams of protein) of buffalograsses.

(DOPA). Polyphenol oxidase activity was observed as dark brown bands on a clear background after $30 \mathrm{~min}$ of incubation (Cheung and Willetts 1973).

Sodium Dodecyl Sulfate-Polyacrylamide Gel Electrophoresis (SDS-PAGE). Samples were separated in $12 \%$ gels (Criterion gel, Bio-Rad) by using the procedures outlined by Laemmli (1970). A continuous buffer system of Tris-glycine-SDS (3 $\mathrm{g}$ of Tris-base, $14.4 \mathrm{~g}$ of glycine, $1 \mathrm{~g}$ of SDS, and $1000 \mathrm{ml}$ of distilled water) (pH 8.3) was used. Samples were diluted 1:1 with a gel loading buffer consisting of $62.5 \mathrm{mM}$ Tris- $\mathrm{HCl}$ (pH 6.8), 0.01\% bromphenol blue, $25 \%$ glycerol, $5 \%$ $\beta$-mercaptoethanol, and $2 \%$ SDS before loading. The protein samples were then heated for $5 \mathrm{~min}$ at $95^{\circ} \mathrm{C}$ before loading on the gel. Equal amounts of protein $(35 \mu \mathrm{g})$ were loaded in each lane. Electrophoresis was conducted at $200 \mathrm{~V}$ for $1 \mathrm{~h}$ at room temperature. Proteins were visualized by silver staining according to standardized methods (Silver Stain, Bio-Rad).

Statistical Analysis. Enzyme activity values were analyzed using mixed model analysis (PROC MIXED, SAS Institute 1997) to detect differences in catalase, peroxidase, and polyphenol oxidase activity between chinch bug-resistant and -susceptible buffalograsses (Littell et al. 1996). Block and block $\times$ treatment were the random effects in the model. When appropriate, means were separated using Fisher's least significant difference (LSD) procedure. This was implemented using the lsmeans statement in PROC MIXED, with the diff option.

\section{Results}

Chinch bugs were observed feeding on infested plants at all harvest dates; however, no evidence of chinch bug damage was observed among infested 378, NE91-118, Cody, and Tatanka plants at day 3, 6, or 9. Infested NE91-118 and Tatanka plants continued to show no chinch bug damage on days 12 and 15. However, 378 and Cody plants had damage ratings of 1.5 and 1.0 on days 12 and 2.0 and 1.3 on day 15 , respectively.

Protein and Enzyme Assays. Total protein content was similar between infested and uninfested Cody and Tatanka plants (Fig. 1). In contrast, infested NE91-118 plants had a higher protein content compared with control plants starting at day 6 (day $3: t=0.1$; df $=7$, $41 ; P=0.92$; day $6: t=1.4 ; \mathrm{df}=7,41 ; P=0.17$; day 9 : $t=2.1 ; \mathrm{df}=7,41 ; P=0.045 ;$ day $12: t=2.9 ; \mathrm{df}=7$, $41 ; P=0.031$; and day $15: t=1.7 ; \mathrm{df}=7,41 ; P=0.046)$. Infested 378 plants showed an overall decline in protein content from the start of the study compared with uninfested controls.

Changes in catalase activities were observed in response to chinch bug feeding (Fig. 2). Infested 378 plants had a lower level of catalase activity compared 

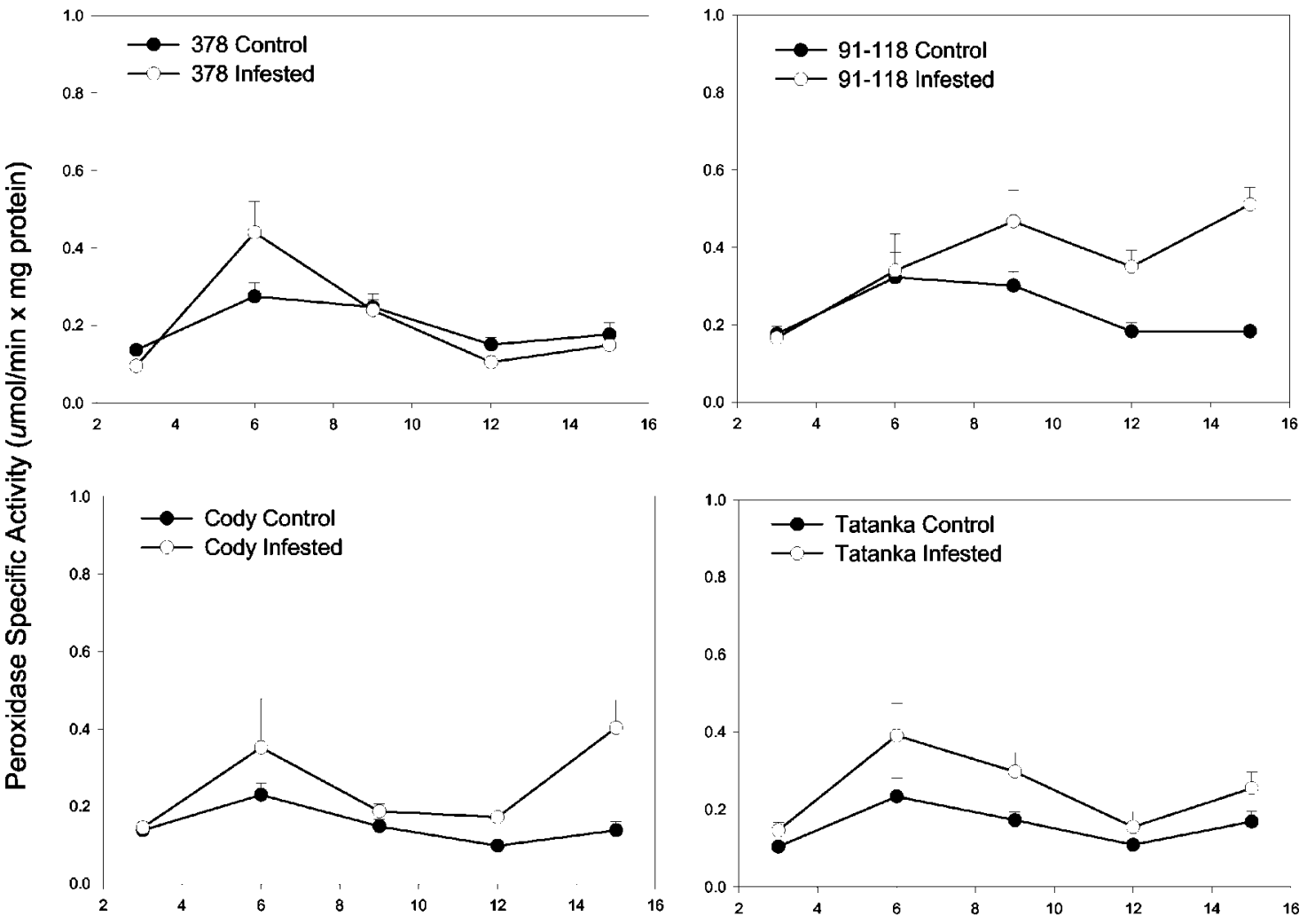

Day

Fig. 3. Peroxidase specific activity (micromoles per minute $\times$ milligrams of protein) of buffalograsses.

with their respective control plants at each evaluation date, except day 3 (day $3: t=0.7 ; \mathrm{df}=7,41 ; P=0.55$; day $6: t=1.2 ; \mathrm{df}=7,41 ; P=0.12$; day $9: t=3.0 ; \mathrm{df}=$ 7,$41 ; P=0.005$; day $12: t=3.2$; df $=7,41 ; P=0.003$; and day $15: t=4.1 ; \mathrm{df}=7,41 ; P=0.002)$. By contrast, catalase activities for infested and control NE91-118, Cody, and Tatanka were similar throughout the study.

Infested NE91-118 plants had higher levels of peroxidase activity compared with their control plants on days 9,12 , and 15 (day $3: t=0.06$; df $=7,41 ; P=0.89$; day $6: t=0.05 ; \mathrm{df}=7,41 ; P=0.94$; day $9: t=2.7 ; \mathrm{df}=$ 7,$41 ; P=0.005$; day $12: t=3.2 ; \mathrm{df}=7,41 ; P=0.003$; and day $15: t=3.9 ; \mathrm{df}=7,41 ; P=0.0008$ ) (Fig. 3). The greatest difference in peroxidase activity between infested and control NE91-118 plants was observed on day 15. Peroxidase activities for control and infested 378 plants remained at similar levels with a slight increase in activity on day 6 during the study (day 3: $t=0.53 ; \mathrm{df}=7,41 ; P=0.62 ;$ day $6: t=1.93$; df $=7$, 41; $P=0.062$; day 9: $t=0.56$; $\mathrm{df}=7,41 ; P=0.62$; day 12: $t=0.15 ; \mathrm{df}=7,41 ; P=0.83$; and day $15: t=1.1$; df $=7,41 ; P=0.28)$. Cody control and infested plants had comparable levels of peroxidase activity on all sample dates, except day 15 when increased levels of peroxidase activity where observed for infested Cody plants (day 3: $t=0.12$; $\mathrm{df}=7,41 ; P=0.95$; day $6: t=$ 1.8 ; df $=7,41 ; P=0.071$; day $9: t=1.0 ; \mathrm{df}=7,41 ; P=$
0.32 ; day $12: t=1.25 ; \mathrm{df}=7,41 ; P=0.47$; and day 15 : $t=1.94 ; \mathrm{df}=7,41 ; P=0.065)$. Infested Tatanka plants consistently had a higher level of peroxidase activity compared with controls (day $3: t=0.41 ; \mathrm{df}=7,41 ; P=$ 0.68; day 6: $t=1.91$; df $=7,41 ; P=0.066$; day $9: t=$ 1.79; $\mathrm{df}=7,41 ; P=0.084$; day $12: t=0.30 ; \mathrm{df}=7,41$; $P=0.76$; and day 15: $t=0.34 ; \mathrm{df}=7,41 ; P=0.73)$.

Polyphenol oxidase activities were similar between control and infested plants for all buffalograsses evaluated (Fig. 4). The lack of differences in polyphenol oxidase activity between control and infested plants demonstrates that this enzyme is not likely to be associated with the resistance.

Gel Electrophoresis. Native Gel Electrophoresis. Among the enzymes examined, no differences in isozyme profiles for peroxidase and polyphenol oxidase were detected between control and infested 378, NE91-118, Cody, and Tatanka plants (Figs. 5 and 6). However, differences in isozyme profiles for peroxidase and polyphenol oxidase were observed among control plants for the buffalograsses. These differences reflect the natural genetic variability among buffalograsses.

Gels stained for catalase identified differences in the isozyme profiles of infested and uninfested 378 plants. Similar isozyme profiles were observed between 378 plants infested with chinch bugs and their 

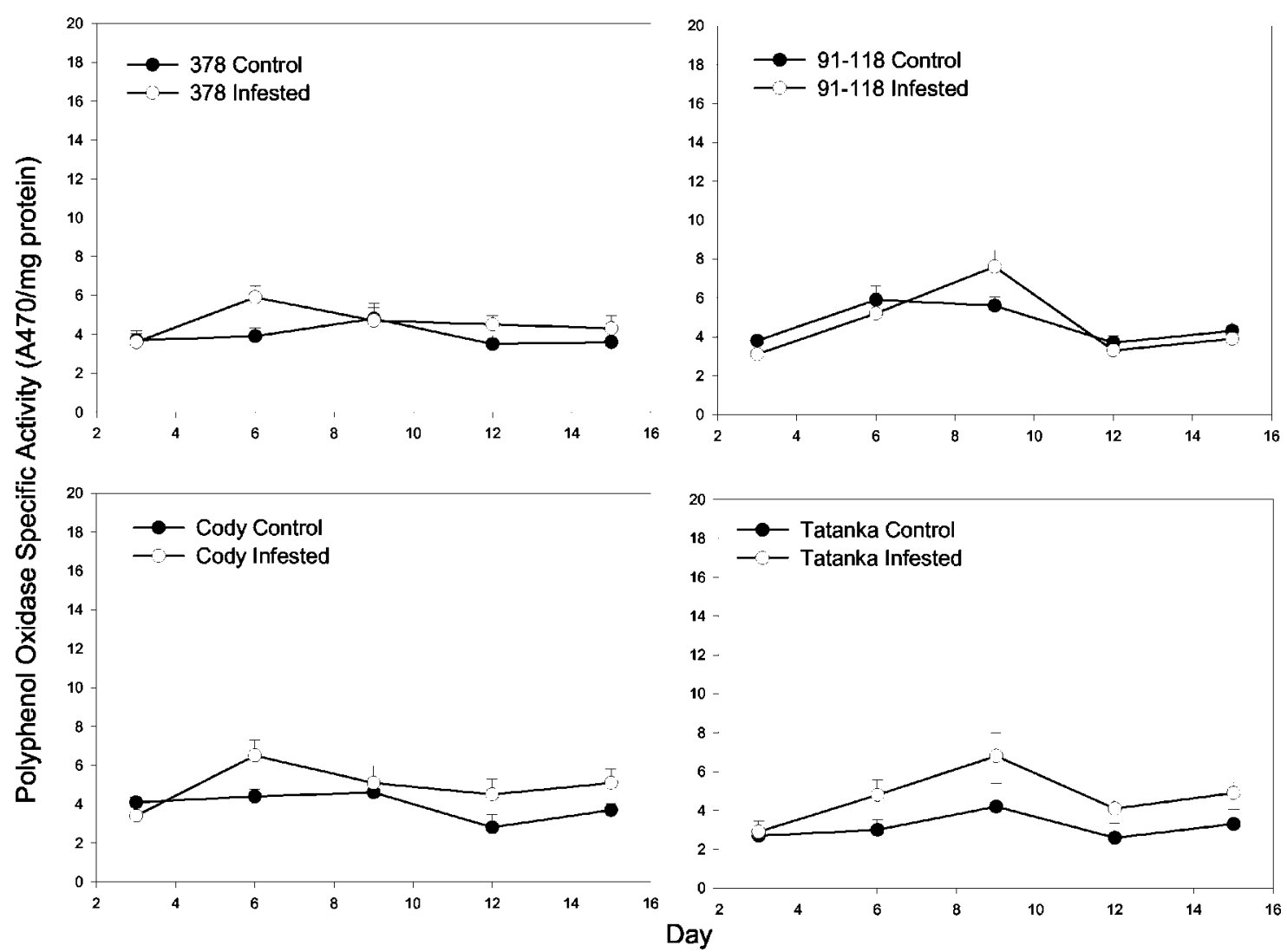

Fig. 4. Polyphenol oxidase specific activity (micromoles per minute $\times$ milligrams of protein) of buffalograsses.

uninfested controls at days 3 and 6 (Fig. 7a). However, starting at day 9 , infested plants showed a decline in catalase activity, whereas uninfested plants had similar isozyme profiles throughout the experiment (Fig. 7b, lanes 1 and 2). Infested and control NE91-118 and Tatanka plants had similar isozyme profiles at all sampling dates. Isozyme profiles for Cody were similar between infested and control plants on each sampling date, except day 15 when one of the three replications suffered chinch bug damage (damage rating $=2$ ) (Fig. 7c, lanes 5 and 6 ). The other two replications showed no visible chinch bug injury (damage rating $=$ 1) (Fig. 7b, lanes 5 and 6). This variability in chinch bug susceptibility resulted in the different isozyme profiles for this seeded cultivar. Notably, as observed for 378, the chinch bug-injured Cody plant showed a loss of catalase activity, whereas the isozyme profiles for both control and infested plants were similar.

SDS Gel Electrophoresis. No differences in protein profiles were observed between chinch bug infested 378, NE91-118, Cody, and Tatanka plants and their respective uninfested controls. All of the buffalograss control plants exhibited similar protein profiles.

\section{Discussion}

Previous reports have demonstrated that plant oxidative enzymes (e.g., peroxidase, polyphenol oxidase, and catalase) play an important role in the plant's response to biotic and abiotic stresses (Van Loon 1976; Castillo et al. 1984; Hildebrand et al. 1986; Zhang and Kirkham 1994; Felton et al. 1994a,b; Stout et al. 1999; Chaman et al. 2001; Ni et al. 2001). Our enzyme activity assays and protein profiles suggest that chinch bug feeding leads to a loss in catalase activity in susceptible buffalograsses. Resistant buffalograsses, however, may be able to tolerate chinch bug feeding by increasing their peroxidase activity. Further research is needed to determine the role of these enzymes in the defense response of buffalograss to chinch bug feeding and to evaluate these differences as potential molecular markers for selecting chinch bug-resistant buffalograsses.

Enzyme activity varied considerably among the three replications of Cody. It is difficult, therefore, to decipher the exact role these enzymes are playing in the defense response of Cody to chinch bug feeding. Unlike vegetatively propagated buffalograsses that have little genetic diversity, seeded buffalograsses such as Cody consist of many genotypes that often display substantial genetic diversity. This genetic diversity may help explain the observed variability in enzyme activities for Cody. Additional information on the genetic composition of this seeded buffalograss is needed before the defensive role of oxidative enzymes can be accurately assessed. 


\section{$\begin{array}{llllllll}1 & 2 & 3 & 4 & 5 & 6 & 7 & 8\end{array}$}

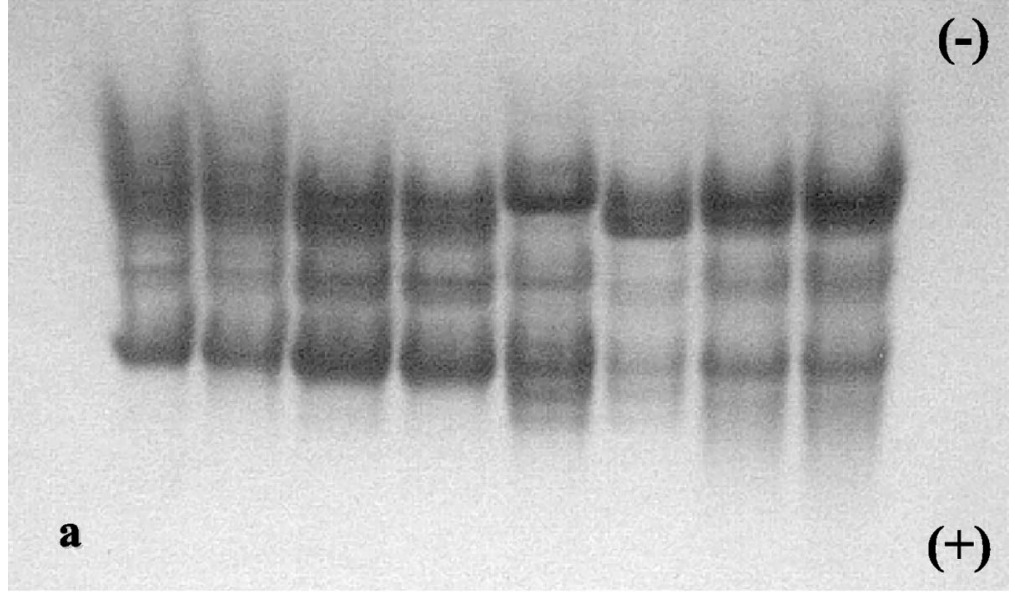

\section{$\begin{array}{llllllll}1 & 2 & 3 & 4 & 5 & 6 & 7 & 8\end{array}$}

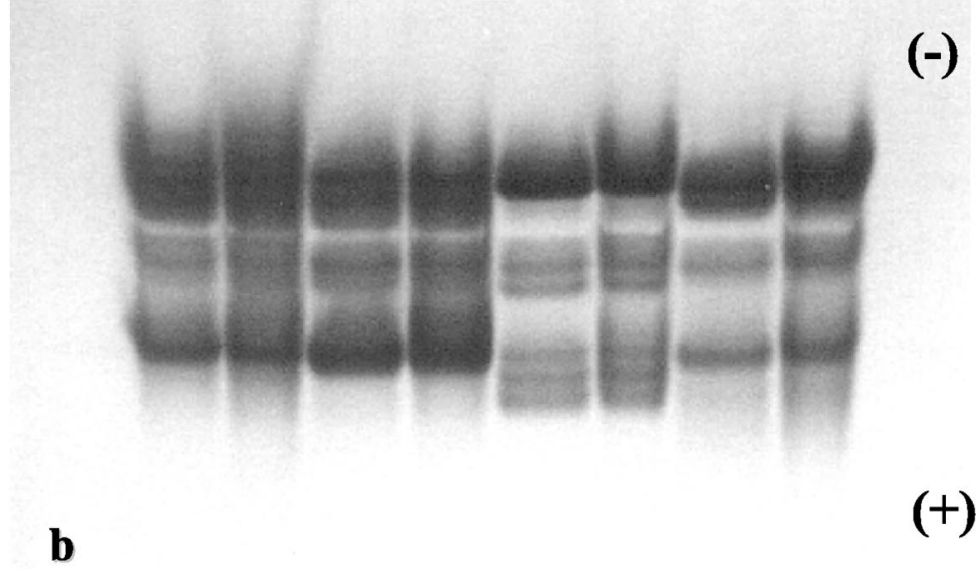

Fig. 5. Native gels stained for peroxidase activity. (a) Top gel $3 \mathrm{~d}$ after chinch bug introduction. (b) Bottom gel $15 \mathrm{~d}$ after introduction. Lane 1, 378-Control; lane 2, 378-Infested; lane 3, NE91-118-Control; lane 4, NE91-118-Infested; lane 5, CodyControl; lane 6, Cody-Infested; lane 7, Tatanka-Control; and lane 8, Tatanka-Infested.

Hydrogen peroxide is thought to be produced in response to plant stress such as insect feeding (Dowd and Lagrimini 1997). The level of hydrogen peroxide is mediated by the presence of oxidative enzymes such as peroxidase and catalase (Levine et al. 1994, Mehdy 1994, Allen 1995). These oxidative enzymes serve to catalyze the reduction of toxic intermediates of oxygen metabolism to prevent cellular damage. Hildebrand et al. (1986) suggested that increased peroxidase activity in resistant plants may allow the plant to detoxify peroxides and therefore sustain less tissue damage than susceptible plants.

Peroxidase is also involved in lignin synthesis in cell walls. Lignification can be beneficial to the plant be- cause it serves to strengthen and reinforce cell walls (Fincher and Stone 1986). The synthesis of lignin in response to insect feeding may provide cell wall reinforcement and thereby increase the plant's tolerance to insect feeding.

The role of peroxidase and other oxidative enzymes as anti-nutritive and/or toxicological defenses against chewing insects has been demonstrated by several studies (Felton et al. 1989, Duffey and Felton 1991, Duffey and Stout 1996). In general, plant tissues generate phenol compounds in their cells in response to biotic stress. Peroxidase and other oxidative enzymes serve to oxidize several of these phenolic compounds in damaged tissues to form reactive quinones (Felton 


\section{$\begin{array}{llllllll}1 & 2 & 3 & 4 & 5 & 6 & 7 & 8\end{array}$}

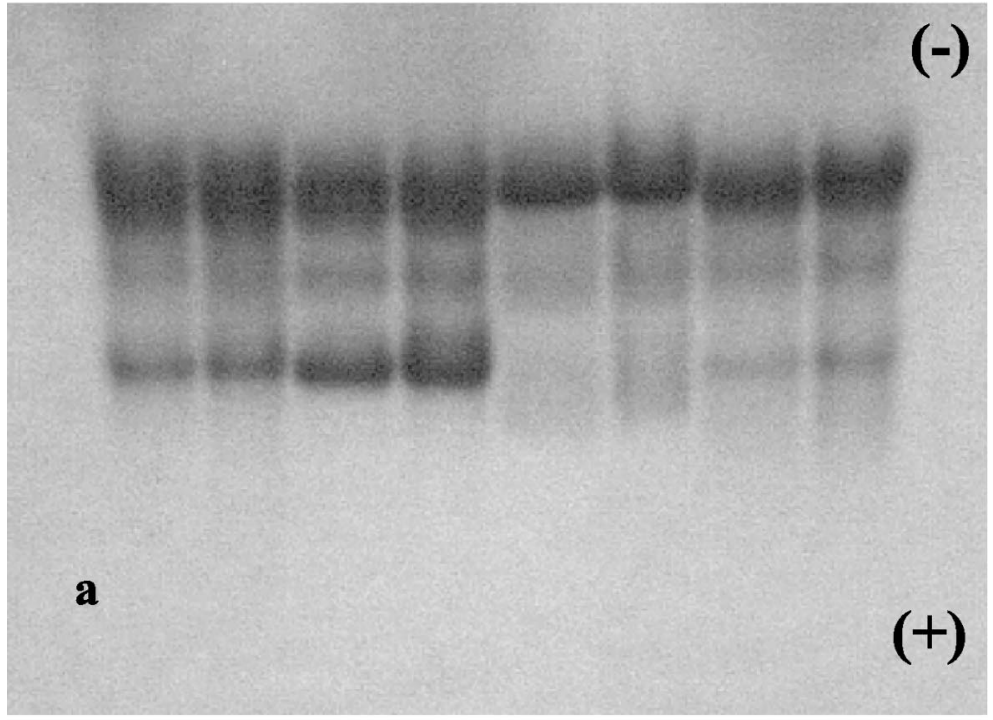

\section{$\begin{array}{llllllll}1 & 2 & 3 & 4 & 5 & 6 & 7 & 8\end{array}$}

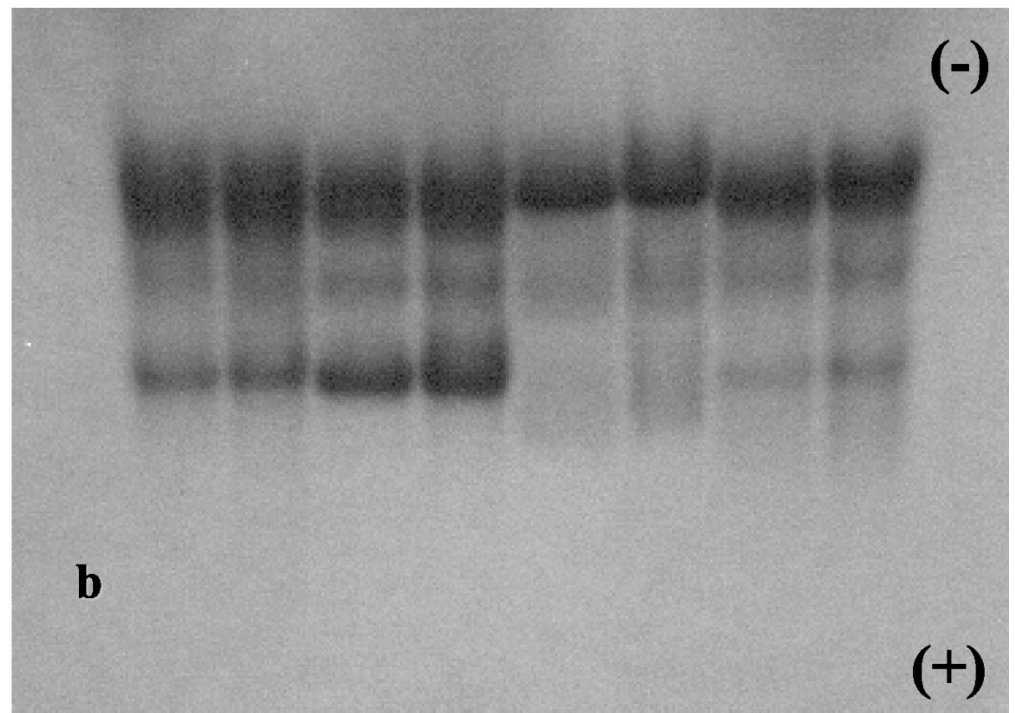

Fig. 6. Native gels stained for polyphenol oxidase activity. (a) Top gel $3 \mathrm{~d}$ after chinch bug introduction. (b) Bottom gel 15 d after introduction. Lane 1, 378-Control; lane 2, 378-Infested; lane 3, NE91-118-Control; lane 4, NE91-118-Infested; lane 5, Cody-Control; lane 6, Cody-Infested; lane 7, Tatanka-Control; and lane 8, Tatanka-Infested.

et al. 1989). Quinones have been shown to pose considerable oxidative stress to herbivores by destroying essential nutrients that are vital to the development of the insect and/ or by their direct toxicity on herbivores (Duffey and Felton 1991, Felton et al. 1994, Duffey and Stout 1996).

Studies conducted by Faccioli (1979), Matkovics et al. (1981), and Hildebrand et al. (1986) found no association between catalase activity and pest resistance (Faccioli 1979, Matkovics et al. 1981, Hildebrand et al. 1986). In our study, increased catalase activity was not associated with increased levels of chinch bug resistance.

This research offers a new perspective on plant resistance to insects and provides a model for studying insect-plant interactions. Furthermore, the identification of protein-mediated markers for insect resistance provides a novel approach for screening insectresistant germplasm. Ultimately, molecular markers identified from this research will provide a set of tools 


\section{$\begin{array}{llllllll}1 & 2 & 3 & 4 & 5 & 6 & 7 & 8\end{array}$}
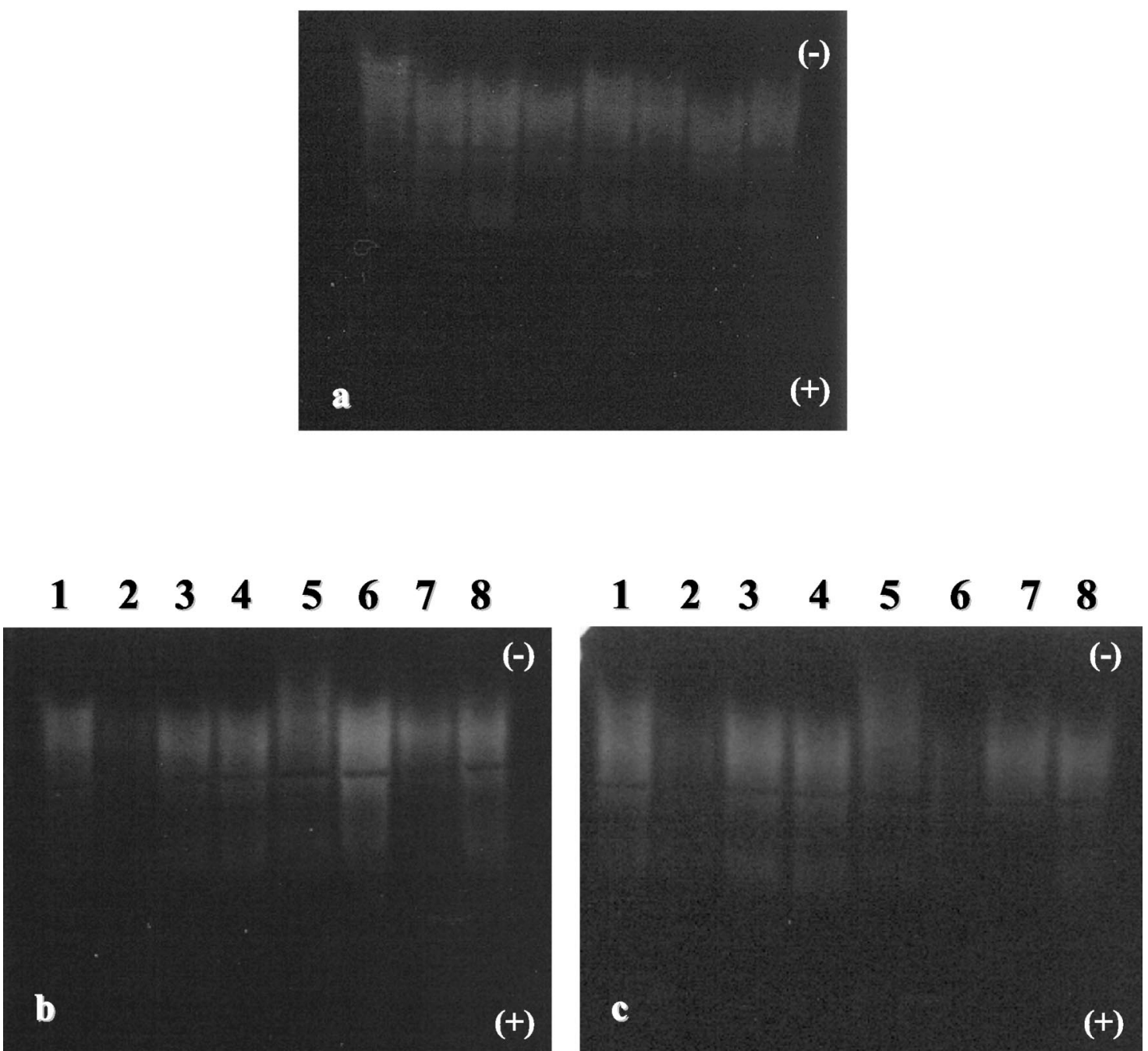

Fig. 7. Native gels stained for catalase activity. (a) Top gel $3 \mathrm{~d}$ after chinch bug introduction. (b) Bottom left gel $15 \mathrm{~d}$ after chinch bug introduction. (c) Bottom right gel $15 \mathrm{~d}$ after introduction. Lane 1, 378-Control; lane 2, 378-Infested; lane 3, NE91-118-Control; lane 4, NE91-118-Infested; lane 5, Cody-Control; lane 6, Cody-Infested; lane 7, TatankaControl; and lane 8, Tatanka-Infested.

for screening other plants for resistance to sap-feeding insects and furnish a starting point for characterizing additional protein-mediated markers specific to insect resistance.

\section{Acknowledgments}

We gratefully acknowledge L. Higley and J. Foster for reviewing this manuscript, and E. Ross, T. Weinhold, and T. Eickhoff (University of Nebraska) for technical assistance. This research was supported in part by the University of Nebraska Agricultural Experiment Station Project 17-051 and 17-078, the United States Golf Association, and the Nebraska Turfgrass Foundation. This is paper number 14298 of the journal series of the Agricultural Research Division, University of Nebraska-Lincoln.

\section{References Cited}

Allen, R. D. 1995. Dissection of oxidative stress tolerance using transgenic plants. Plant Physiol. 107: 1049-1054.

Baxendale, F. P., T. M. Heng-Moss, and T. P. Riordan. 1999. Blissus occiduus Barber (Hemiptera: Lygaeidae): a new chinch bug pest of buffalograss turf. J. Econ. Entomol. 92: 1172-1176.

Bradford, M. M. 1976. A rapid and sensitive method for the quantification of microgram quantities of protein utilizing the principle of protein-dye binding. Anal. Biochem. 72: 248-254.

Castillo, F. J., C. Penel, and H. Greppin. 1984. Peroxide release induced by ozone in Sedum album leaves: involvement of $\mathrm{Ca}^{2+}$. Plant Physiol. 74: 846-851.

Chaman, M. E., L. J. Corcuera, G. E. Zuniga, L. Cardemil, and V.H. Argandona. 2001. Induction of soluble and cell 
wall peroxidases by aphid infestation in barley. J. Agric. Food Chem. 49: 2249-2253.

Cheung, D.S.M., and H. J. Willetts. 1973. Isozymes of pdiphenol oxidase in the stem rust-wheat interacting system. Arch. Mikrobiol. 92: 263-266.

Dowd, P., and L. M. Lagrimini. 1997. The role of peroxidase in host insect defense, 195-223. In N. Carozzi and M. Koziel [eds.], Advances in insect control. Taylor \& Francis, Ltd., London, England.

Duffey, S. S., and G. W. Felton. 1991. Enzymatic anutritive defenses of the tomato plants against insects, pp. 167-197. In P. A. Hedin [ed.], Naturally occurring pest bioregulators. Am. Chem. Soc. Symp. Ser. 449. Dallas, 1989. American Chemical Society, Washington, DC.

Duffey, S. S., and M. J. Stout. 1996. Anutritive and toxic compounds of plant defense against insects. Arch. Insect Biochem. Physiol. 32: 3-37.

Faccioli, G. 1979. Relation of peroxidase, catalase, and polyphenoloxidase to acquired resistance in plants of Chenopodium amaranticolor locally infected by tobacco necrosis virus. Phytopathol. Z. 95: 237-249.

Felton, G. W., R. J. Donato, D. Vecchio, and S. S. Duffey. 1989. Activation of plant foliar oxidases by insect feeding reduces nutritive quality of foliage for noctuid herbivores. J. Chem. Ecol. 15: 2667-2694.

Felton, G. W., C. B. Summers, and A. J. Mueller. 1994a. Oxidative responses in soybean foliage to herbivory by bean leaf beetle and three-corned alfalfa leafhopper. J. Chem. Ecol. 20: 639-650.

Felton, G. W., J. L. Bi, C. B. Summers, A. J. Mueller, and S. S. Duffey. 1994b. Potential role of lipoxygenases in defense against insect herbivory. J. Chem. Ecol. 20: 651666.

Fincher, G. B., and B. A. Stone. 1986. Cells walls and their components in cereal grain technology. Adv. Cereal Sci. Technol. 8: 207-295.

Green, T. R., and C. A. Ryan. 1972. Wound-induced proteinase inhibitors in plant leaves: a possible defense mechanism against insects. Science 175: 776-777.

Heng-Moss, T. M., F. P. Baxendale, T. P. Riordan, and J. E. Foster. 2002. Evaluation of buffalograss germplasm for resistance to Blissus occiduus. J. Econ. Entomol. 95: $1054-1058$.

Hildebrand, D. F., J. G. Rodriguez, G. C. Brown, K. T. Luu, and C. S. Volden. 1986. Peroxidative responses of leaves in two soybean genotypes injured by twospotted spider mites (Acari: Tetranychidae). J. Econ. Entomol. 79: 14591465.

Hori, K., A. Wada, and T. Shibuta. 1997. Changes in phenoloxidase activities of the gals on leaves of Ulmus davidana formed by Tetraneura fusiformis (Homoptera: Eriosomatidae). Appl. Entomol. Zool. 32: 365-371.
Jerez, M. I. 1998. Response of two maize inbred lines to chinch bug feeding. M.S. thesis, Mississippi State University, Mississippi.

Laemmli, U. K. 1970. Cleavage of structural proteins during the assembly of the head of the bacteriophage T4. Nature (Lond.) 227: 680-685.

Levine, A., R. Tenhaken, R. Dixon, and C. Lamb. 1994 Hydrogen peroxide from the oxidative burst orchestrates the plant hypersensitive response. Cell 79: 583-593.

Littell, R. C., G. A. Milliken, W. W. Stroup, and R. D. Wolfinger. 1996. SAS system for mixed model. SAS Institute, Cary, NC.

Matkovics, B., L. Szabo, and S. I. Varga. 1981. Study of hostparasite interaction in tomato plants. Acta Univ. Szeged. Acta Biol. 27: 17-23.

Mehdy, M. C. 1994. Active oxygen species in plant defense against pathogens. Plant Physiol. 105: 467-472.

Miller, H., D. R. Porter, J. D. Burd, D. W. Mornhinweg, and R. L. Burton. 1994. Physiological effects of Russian wheat aphid (Homoptera: Aphididae) on resistant and susceptible barley. J. Econ. Entomol. 87: 493-499.

Ni, X., S. S. Quisenberry, T. Heng-Moss, J. Markwell, G. Sarath, R. Klucas, and F. Baxendale. 2001. Oxidative responses of resistant and susceptible cereal leaves to symptomatic and non-symptomatic cereal aphid (Hemiptera: Aphididae) feeding. J. Econ. Entomol. 94: 743-751.

Rafi, M. M., R. S. Zemetra, and S. S. Quisenberry. 1996. Interaction between Russian wheat aphid (Homoptera: Aphididae) and resistant and susceptible genotypes of wheat. J. Econ. Entomol. 89: 239-246.

SAS Institute. 1997. SAS/STAT Software: changes and enhancements through release 6.12. SAS Institute, Cary, NC.

Stout, M. J., A. L. Fidantsef, S. S. Duffey, and R. M. Bostock. 1999. Signal interactions in pathogen and insect attack: systemic plant-mediated interactions between pathogens and herbivores of the tomato, Lycopersicon esculentum Physiol. Mol. Plant Pathol. 54: 115-130.

Vallejos, C. E. 1983. Enzyme activity staining, pp. 469-516. In S. D. Tanksley and T. J. Orton [eds.], Isozymes in plant genetics and breeding, part A. Elsevier, Amsterdam, Netherlands.

Van Loon, L. C. 1976. Systemic acquired resistance, peroxidase activity and lesion size in tobacco reacting hypersensitively to tobacco mosaic virus. Physiol. Plant Pathol. 8: 231-242.

Zhang, J., and M. B. Kirkham. 1994. Drought-stress-induced changes in activities of superoxide dismutase, catalase, and peroxidase in wheat species. Plant Cell Physiol. 35 $758-791$.

Received 13 October 2003; accepted 26 January 2004. 